\title{
IMPLEMENTASI KEBIJAKAN PEMBANGUNAN KEKUATAN PERTAHANAN UDARA
}

\author{
Sri Widodo \\ Dosen Manajemen Unsurya \\ wiedsa82@gmail.com
}

\begin{abstract}
Abstrak
Tujuan penelitian ini untuk mengetahui implementasi kebijakan pembangunan kekuatan pertahanan udara periode 1990-2013. Penelitian ini menggunakan metode kualitatif dengan analisis deskriptif.

Hasil penelitian menunjukkan: 1) Lebih dari 40 tahun (1962-2005) tidak ada kebijakan modernisasi PSU; 2) Ada intervensi pimpinan pada kebijakan pengadaan Rudal QW-3 sehingga tidak dapat digunakan sebagai unsur dalam Sishanudnas; 3) Kebijakan pengadaan Radar Smart Hunter tidak ada koordinasi para pihak akibatnya Rudal QW-3 tidak dapat terintegrasi dengan Radar Hanud dalam Sishanudnas; 4) terjadi bias persepsi pada kebijakan pengadaan PSU antara Mabes TNI dan Mabesau tentang Opsreq dan Spektek PSU, sehingga dari tahun 2005-2013 bersifat "status quo".

Kesimpulan penelitian menunjukkan: 1) Terjadi gap pada personel pengambil keputusan kebijakan pembangunan kekuatan Hanud; 2) Tidak sinkronnya kebijakan pengadaan PSU dengan kebutuhan operasi; 3) Tidak sinkronnya kekuatan senjata dengan kekuatan personel dan organisasi. Hal ini disebabkan oleh adanya kecenderungan penguasa/pemimpin mempergunakan Governant Politics Model atau Dominant Leader Model yaitu pengambilan keputusan berdasarkan pada selera penguasa dan kekuasaan.

Disarankan agar pengadaan PSU menganut kebijakan bottom-up, berdasarkan kebutuhan operasi dan teknologi terkini, sinkron antara kekuatan senjata dengan kekuatan personel dan organisasi.
\end{abstract}

Kata Kunci: Kebijakan, pembangunan kekuatan, pertahanan udara.

\section{PENDAHULUAN}

Pertahanan negara Indonesia ideal masih sulit diwujudkan, sedangkan negara-negara tetangga semakin meningkatkan kekuatan militernya yang dapat menjurus pada ancaman militer. Pelanggaran wilayah udara Indonesia di atas perairan Pulau Bawean oleh 5 pesawat F-18 Hornet US Navy pada tanggal 3 Juli 2003 merupakan bukti bahwa wilayah udara Indonesia masih sangat rawan terhadap ancaman (Wresniwiro, 2004:245). Fenomena ini menuntut adanya pertahanan negara yang tangguh, namun minimnya alokasi anggaran negara berimplikasi pada rendahnya kekuatan TNI. TNI AU sebagai unsur TNI, salah satu tugas untuk mengamankan wilayah udara nasional menjadi wewenang dan tanggung jawab Komando Pertahanan Udara Nasional (Kohanudnas) yang dilaksanakan menggunakan sarana Sistem Pertahanan Udara Nasional (Sishanudnas).

Berdasarkan fakta sejarah, kejayaan Kohanudnas dicapai pada tahun 1960-an. Pada periode ini keberadaan peluru kendali (rudal) 
darat-udara jarak menengah SAM-75, radar Hanud dan pesawat tempur sergap Indonesia diperhitungkan di kawasan regional dan global karena memiliki deterrence effect yang tinggi. Namun, sejak tahun 1982 Rudal SAM-75 tersebut di non-aktifkan, sehingga Indonesia belum memiliki pengganti rudal darat-udara jarak pendek dan menengah yang berfungsi sebagai Hanud. Fenomena ini menjadi permasalahan dalam Sishanudnas. Ditinjau dari strategi penangkalan, bahwa kekuatan Hanud TNI AU yaitu Penangkis Serangan Udara (PSU) belum dapat diwujudkan secara optimal, sedangkan beberapa Lanud induk TNI AU belum seluruhnya dilindungi dengan gelar PSU. Kondisi ini bertentangan dengan doktrin TNI (2010: 33) yang menyatakan bahwa pembangunan kekuatan TNI ditujukan untuk mencapai tingkat kemampuan penangkalan 'deterrence capability' yang disegani negara lain, dan diarahkan pada terwujudnya kualitas prajurit yang profesional dan andal; Alutsista yang modern; serta organisasi yang efektif dan efisien. Hal ini menjadi suatu permasalahan penting dan dicarikan solusinya. Untuk itu, perlu adanya implementasi kebijakan pembangunan kekuatan Hanud yang menjadi inti kekuatan dari Kohanudnas.

\section{TINJAUAN TEORI}

\section{Kebijakan}

Kebijakan didefinisikan sebagai 'langkah tindakan yang secara sengaja dilakukan oleh seorang aktor atau sejumlah aktor berkenaan dengan adanya masalah atau persoalan tertentu yang dihadapi' (Anderson dalam Wahab, 2010: 3). Menurut Kebijakan publik yang ideal yaitu yang unggul, mempunyai tiga ciri utama yang sekaligus dijadikan sebagai kriteria, yaitu: Pertama, cerdas...memecahkan masalah pada inti_permasalahannya. Kecerdasan membuat pengambil keputusan kebijakan publik fokus pada isu kebijakan yang hendak dikelola dalam kebijakan publik daripada popularitas sebagai pengambil keputusan kebijakan; Kedua, bijaksana...tidak menghasilkan masalah baru yang lebih besar daripada masalah yang dipecahkan; Ketiga, memberikan harapan kepada seluruh warga bahwa mereka dapat memasuki hari esok lebih baik dari hari ini. (Nugroho, 2009:706).

Kebijakan publik dijabarkan dalam makna kebijakan publik, yaitu hal-hal yang "diputuskan" pemerintah untuk "dikerjakan", dan hal-hal yang "diputuskan" pemerintah untuk "tidak dikerjakan" atau "dibiarkan" (Nugroho, 2009:145).

Dalam konteks PSU, cenderung memperoleh respon dari pembuat kebijakan kalau memenuhi kriteria, salah satunya adalah telah mencapai suatu titik kritis tertentu. Namun 'pejabat senior pemerintah (sipil atau militer) yang berpengaruh akan semakin kukuh jika mereka dipersepsikan sebagai memiliki legitimasi dan kekuasaan atas isu tersebut. Pandangan mereka atas isu yang diperdebatkan dianggap memiliki nilai keabsahan tertentu' (Wahab, 2010:41).

Kesalahan mendasar dari pembuat kebijakan publik adalah hanya mengandalkan 
semua dalam kondisi ideal. Kebijakan publik seperti itu sebagai 'kebijakan yang baik tetapi tidak benar.' Artinya, perumusannya baik, namun tidak benar karena ada intervensi. Setiap kebijakan harus mendapatkan legitimasi pembenarannya secara hukum atau harus sesuai dengan tata peraturan/perundang-undangan yang berlaku (Indiahono, 2009: 142).

Hal hakiki kebijakan publik adalah: ditujukan untuk melakukan intervensi dan mempunyai keterbatasan, yakni: waktu; kemampuan sumber daya manusia; kelembagaan; dana/anggaran; bersifat teknis. Implementasi sebuah program perlu dukungan, koordinasi dan kerjasama antar instansi bagi keberhasilan suatu program (Subarsono, 2010:100). Ada kecenderungan penguasa atau pemimpin mempergunakan Government Politics Model atau Dominant Leader Model yaitu pengambilan keputusan berdasarkan pada selera penguasa dan kekuasaan (Hill dkk dalam Nugroho, 2009:480).

\section{Deterrence (Penangkalan)}

Robert Jervis (dalam Perkasa, 2011) menyatakan bahwa 'aktor berupaya untuk meningkatkan kemampuan dan kekuatannya untuk menangkal serangan dari lawan, atau setidaknya menekan dan memaksa lawan untuk berpikir kembali untuk melakukan serangan'. Menurut George dan Smoke (dalam Kopiitudashat, 2009) bahwa 'keadaan yang memungkinkan terjadinya deterrence adalah ada ketersediaan teknologi yang memungkinkan pengembangan senjata yang efektif untuk menakut-nakuti lawan.

PSU sebagai unsur Sishanudnas harus memiliki kekuatan berteknologi tinggi untuk menangkal setiap ancaman udara sesuai peran dan fungsinya dalam mendukung operasional Kohanudnas. Untuk itu, perlu kebijakan pembangunan kekuatan Hanud TNI AU atau PSU untuk mengamankan Lanud induk TNI AU di seluruh wilayah Indonesia. Tergelarnya kekuatan PSU di seluruh Lanud induk TNI AU merupakan deterrent effect bagi calon lawan yang berniat menyerang Indonesia. Tercapainya gelar kekuatan PSU sebagai subsistem Sishanudnas akan mendukung keberhasilan operasional Kohanudnas. Dengan demikian, maka kemampuan operasional Kohanudnas akan memberikan kontribusi positif terhadap sistem pertahanan negara dalam kondisi damai maupun perang.

Apabila kemampuan operasional Kohanudnas tidak optimal, kemungkinan tidak tertanggulanginya ancaman melalui udara akan sangat besar. Hal ini menjadi salah satu relevansi pertimbangan dilaksanakannya penelitian kebijakan pembangunan Hanud, karena secara konsep Sishanudnas cukup baik, namun dalam pelaksanaannya belum optimal.

\section{Persepsi}

Persepsi didefinisikan sebagai proses perolehan, penafsiran, pemilihan, dan pengaturan informasi indrawi (Sarwono dan Meinarno, 2009: 24). Manusia seringkali menggunakan diri mereka sendiri sebagai patokan untuk 
mempersepsi pihak lain. Kondisi emosional seseorang banyak berhubungan dengan persepsipersepsi, sehingga sangat sulit untuk menentukan keadaan emosional seseorang. Emosi-emosi yang kuat seringkali menyebabkan bahwa persepsi mengalami distorsi (Winardi, 2009:211). Bayangkan jika seluruh aktivitas atau perilaku kita terdorong dan termotivasi hanya karena emosi dan persepsi, bukan karena suara hati.

Dalam pengambilan keputusan atau sikap,jika didasarkan pada suara hati spiritual, maka akan memiliki kebenaran hakiki. Jika pengambilan keputusan didasarkan pada keadilan dan kejujuran, maka keputusan itu adalah keputusan spiritual. Jika pengambilan keputusan didasarkan pada emosi, maka keputusan itu adalah keputusan emosional. Sedangkan, jika pengambilan keputusan didasarkan pada belenggu persepsi dan paradigma prasangka negatif, maka keputusan itu adalah keputusan persepsi. Jika keputusan spiritual diambil, umumnya akan dibarengi dengan munculnya perasaan damai dan kebahagiaan. Hal ini akan memperoleh sebuah kebahagiaan tersendiri dan dinamakan puncak spiritual atau the ultimate meaning (Agustian, 2004: 157). Namun, jika keputusan yang diambil dengan menggunakan kacamata 'persepsi' dan kepentingan, seringkali menimbulkan kegelisahan yang berkepanjangan. Bahkan, hasil keputusan itu akan mengarah pada terjadinya konflik, baik konflik diri (batin) atau dengan orang lain.

Informasi yang diperoleh melalui persepsi tentang suatu situasi atau masalah melibatkan bias antara fakta situasi obyektif dengan realitas individual yang bersifat subyektif. Bias persepsi ini akan mempengaruhi interpretasi dan reaksi individu terhadap situasi yang berpengaruh terhadap pengambilan keputusan.

\section{Sishanudnas}

Kohanudnas dalam melaksanakan operasi udara menggunakan Sishanudnas beserta unsurunsurnya dengan menggelar kekuatan Hanud di seluruh wilayah Indonesia. Gelar PSU diatur sedemikian rupa agar operasionalisasi Sishanudnas dapat efektif dan efisien.

Dalam operasinya, Kohanudnas memerlukan Hanud TNI AU sebagai sarana penindakan pada area dengan cakupan radius 018 km. Jika PSU sebagai unsur Sishanudnas tidak dapat berinteraksi dengan unsur lainnya dalam Sishanudnas karena rendahnya kekuatan, maka operasi Sishanudnas tidak akan berhasil secara optimal dalam mendukung operasional Kohanudnas.

Proses deteksi, identifikasi dan pengambilan keputusan penindakan dilakukan dalam hitungan detik/menit. Penggunaan doktrin defence in depth seperti lazim digunakan dalam sistem pertahanan udara secara universal, termasuk dianut sebagai doktrin pelaksanaan dalam operasi Kohanudnas. Penggunaan doktrin ini dipengaruhi oleh kemampuan Alutsista dan teknologi persenjataan terutama jarak jangkau.

Doktrin defence in depth menjadi pola operasi pertahanan udara. Pada jarak $100 \mathrm{Km}$ dari obyek yang dipertahankan sampai jarak maksimum deteksi Radar ( $\pm 450 \mathrm{Km})$, penindakan dilaksanakan oleh pesawat Tempur 
Sergap (TS) atau Hanud Area. Jarak 18 Km $100 \mathrm{Km}$ (Hanud Terminal) penindakan dilaksanakan oleh Rudal darat-udara jarak sedang. Jarak $0 \mathrm{Km}-18 \mathrm{Km}$ (Hanud Titik) penindakan dilaksanakan oleh Rudal daratudara jarak pendek.

Penelitian ini didukung beberapa penelitian terdahulu yang relevan, diantaranya penelitian Priyono (2010) menyimpulkan bahwa kemampuan integrasi merupakan salah satu kriteria kemampuan Rudal yang harus dimiliki. Sedangkan penelitian Suparman (2010) menyimpulkan bahwa operasional Kohanudnas belum optimal, karena struktur organisasi dan Sishanudnas tidak dapat bersinergi secara memadai. Hal tersebut dibuktikan oleh hasil penelitian bahwa subsistem Rudal tidak memadai. Rudal yang dimiliki TNI AU hanya untuk Hanud seperti Rudal QW-3. Dengan kemajuan teknologi, efektivitas Rudal ini kurang mampu jika melawan pesawat yang dapat meluncurkan Rudal udara ke darat dari jarak $\pm 100 \mathrm{~km}$ dari sasaran yang dipertahankan. Selain itu, penelitian Hakim (2010) menyimpulkan bahwa keberadaan Kohanudnas tidak didukung dengan peralatan, personel serta dana yang memadai untuk dapat melaksanakan tugasnya. Bahkan penelitian Mardjono (2005) menyatakan bahwa untuk mengimbangi kekuatan udara pihak lain, prioritas deterrent yang harus diwujudkan dengan melakukan pembangunan kekuatan TNI AU berupa pesawat Tempur Sergap dan Rudal Darat-Udara, serta Penangkis Serangan Udara (PSU).

\section{METODOLOGI PENELITIAN}

Penelitian ini menggunakan metode kualitatif dengan mengkombinasikan analisis deskriptif dan penelitian tindakan. Informan yang memiliki pengetahuan dan informasi terkait penelitian dipilih secara purposive. Teknik pengumpulan data meliputi: Observasi Non-partisipasi; Wawancara semi terstruktur; Dokumentasi; dan Triangulasi. Peneliti menggunakan teknik analisis Miles dan Huberman (dalam Sugiyono, 2013: 246) yaitu: Reduksi data; penyajian data; dan menarik kesimpulan.

\section{HASIL PENELITIAN}

Senjata meriam Hanud atau PSU buatan Swiss tahun 1950 dioperasikan TNI AU sejak tahun 1962. Sejak diterima TNI AU senjata Hanud tersebut tidak memiliki sertifikat kelaikan dan buku manual.

Pada tahun 1986 (setelah 25 tahun dioperasikan), 12 meriam Hanud rusak berat dan dijadikan monumen. Tahun 1990 Korpaskhas mengusulkan penggantian meriam Hanud jenis Sky Guard (Oerlikon, Swiss), seperti penjelasan informan berikut:

"Akhir tahun 1990 sudah ada kebijakan untuk
penggantian meriam Hanud, seperti pengajuan
dari Korpaskhas yaitu jenis Sky Guard buatan
Oerlikon, Swiss. Mabesau sudah menindak
lanjuti dengan mencari berbagai kemungkinan
meriam Hanud pengganti. Namun, atas
kebijaksanaan pimpinan TNI AU saat itu, diganti
dengan pengadaan Rudal Manpack QW-3". Tahun 1993, meriam Hanud mengalami accident di Cipatat dan melukai personel Korpaskhas yang mengawakinya. Dari data 
temuan penelitian diketahui bahwa sejak tahun 1995 pabrik pembuat persenjatan Hanud tersebut sudah tidak berproduksi, seperti penjelasan informan berikut:

"Dalam mendukung kesiapan meriam Hanud dirasakan semakin sulit karena tahun 1995 pabrik pembuat meriam Hanud, Swiss sudah tidak memproduksi lagi atau tutup".

Akibat tutupnya pabrik meriam Hanud tersebut, dukungan suku cadang sulit didapatkan. Dalam melaksanakan pemeliharaan tingkat berat (overhaul) kebutuhan suku cadang terpaksa dilaksanakan kanibalisasi komponen.

Pada tahun 1999 meriam Hanud terjadi kecelakaan lagi di Pacitan dengan korban personel Korpaskhas meninggal dunia. Setelah kejadian ini Korpaskhas tidak pernah mendapat pendidikan dan pelatihan senjata Hanud dan tidak memiliki personel inspektor.

Tahun 2004 TNI AU mendapat alokasi Rudal QW-3 dengan date of expired (DOE) 10 tahun sejak diproduksi. Rudal QW-3 pada awalnya tidak dapat terintegrasi dengan Radar Hanud, seperti penjelasan informan berikut:

"Sejak awal Rudal QW-3 tidak dapat terintegrasi dengan Radar Hanud yang dimiliki TNI AU. Hanya sebatas informasi lisan dari Pos Komando melalui radio komunikasi (HT) tentang arah dan jarak sasaran".

Dalam pengadaan Rudal QW-3, penjelasan informan dari Mabesau sebagai berikut:

"Korpaskhas hanya menerima hasil kebijakan Komando Atas dan tidak pernah mengajukan kebutuhan Rudal QW-3 tersebut. Rudal QW-3 tersebut secara yuridis belum ada ketentuan standarisasi sebagai Rudal Taktis".
Pada tahun 2005 ada program pengadaan PSU TNI AU untuk mengganti persenjataan lama. Referensi yang digunakan adalah Peraturan Kasau Nomor: Perkasau/82/VI/2007 tanggal 30 Juni 2007 tentang Petunjuk Pelaksanaan TNI AU tentang Operational Requirements Satuan Jajaran TNI AU. Petunjuk Pelaksanaan tersebut salah satunya untuk menentukan parameter Hanud (PSU) sebagai unsur Sishanudnas.

Namun sampai saat penelitian ini dilaksanakan, pengadaan PSU belum dapat direalisasikan karena terjadi bias persepsi antara Mabes TNI dengan Mabesau pada aspek teknis (operational requirements dan spesifikasi teknis) PSU yang akan dibeli. Mabes TNI menggunakan operational requirements tahun 2004 sedangkan TNI AU menggunakan operational requirements tahun 2007.

Berdasarkan temuan penelitian diketahui bahwa Rudal QW-3 belum dapat terintegrasi dengan Radar Hanud dalam Sishanudnas. Untuk menjembatani Rudal QW-3 agar dapat terintegrasi dengan Radar Hanud dalam Sishanudnas, pada tahun 2010 ada kebijakan pengadaan dan alokasi Radar Smart Hunter.

\section{PEMBAHASAN}

Tolok ukur sebagai indikator keberhasilan yang digunakan yaitu: 1) Peraturan Kasau nomor: Perkasau/82/VI/2007 tanggal 30 Juni 2007 tentang Operational Requirements Satuan Jajaran TNI AU dengan muatan teknologi terkini; 2) Sishanudnas. 
Senjata meriam Hanud (PSU) sejak digunakan TNI AU tahun 1962 tidak ada buku manual dan tidak memiliki sertifikat kelaikan, bahkan sampai dengan tahun 1990 (selama 28 tahun) masih dioperasikan dan tidak ada kebijakan modernisasi. Pada tahun 1990 Korpaskhas mengusulkan senjata meriam pengganti yaitu jenis Skyguard buatan Oerlikon Swiss. Namun, sesuai kebijakan pimpinan TNI AU saat itu diganti dengan pengadaan Rudal QW-3.

Hal ini disebabkan oleh keterbatasan: pengetahuan, praktik manajemen profesional, dan aspek teknis, serta pengaruh bias persepsi dari pemimpin (penguasa) dalam pengambilan keputusan kebijakan.

Analisis penelitian ini mengkombinasikan metode deskriptif dan penelitian tindakan, dengan hasil data temuan sebagai berikut:

Pertama, tidak adanya sertifikat kelaikan dan buku manual sejak awal dioperasikan, sudah menyalahi ketentuan kelaikan dan keselamatan kerja. Seharusnya personel kebijakan melarang meriam Hanud untuk dioperasikan jika tanpa sertifikat kelaikan dan buku manual, namun senyatanya meriam Hanud (PSU) masih dioperasikan.

Selain itu, sejak awal meriam Hanud tersebut sering mengalam kemacetan saat dioperasikan, tidak ada inspektor, personel yang mengawaki meriam tersebut tidak mendapat pendidikan dan pelatihan, serta di seluruh dunia hanya Indonesia (TNI AU) saja yang mengoperasikan. Pada tahun 1995 pabrik sudah tutup, sehingga terbatas dukungan suku cadang.
Hal ini merupakan bukti empirik bahwa senjata meriam Hanud tidak layak dioperasikan. Seharusnya personel pengambil keputusan kebijakan menerapkan implementasi kebijakan untuk melarang pengoperasian meriam Hanud tersebut dan mengganti dengan pengadaan meriam Hanud baru. Tetapi senyatanya, meriam Hanud tersebut masih dioperasikan hingga tahun 2013 (selama 51 tahun) dan belum ada penggantian atau pengadaan meriam baru. Jadi, penerapan implementasi kebijakan oleh personel pengambil keputusan kebijakan selain memiliki keterbatasan pengetahuan, praktik manajemen profesional dan hal bersifat teknis, ada bias persepsi dan intervensi dari pemimpin (penguasa) dalam pengambilan keputusan kebijakan. Hal ini selaras dengan pendapat Hill dkk (dalam Nugroho, 2009:480) bahwa ada kecenderungan penguasa atau pemimpin mempergunakan Government Politics Model atau Dominant Leader Model yaitu pengambilan keputusan berdasarkan pada selera penguasa dan kekuasaan.

Kedua, personel Korpaskhas yang mengawaki meriam Hanud tidak menerima pendidikan dan pelatihan lagi; tidak memiliki personel inspektor; senjata meriam sering mengalami kemacetan saat dioperasikan, tahun 1995 pabrik sudah tutup/tidak berproduksi lagi, sehingga terbatas suku cadang. Dengan datadata tersebut, seharusnya personel pengambil keputusan kebijakan segera menerapkan implementasi kebijakan untuk melarang dioperasikannya meriam Hanud tersebut. Tetapi senyatanya, sampai dengan akhir tahun 2013 
(selama 51 tahun) meriam Hanud tersebut masih tetap dioperasikan. Seharusnya setelah meriam Hanud mengalami accident dua kali dan ada korban personel diambil tindakan atau 'action' yaitu senjata meriam tersebut dilarang dioperasikan, tetapi senyatanya tidak ada action sama sekali.

Dari pembahasan tersebut, disimpulkan sebagai berikut:

Pertama, tidak ada implementasi kebijakan untuk melarang pengoperasian meriam tersebut setelah mengalami dua kali accident, senjata meriam Hanud sering mengalami kemacetan saat dioperasikan, tidak memiliki surat kelaikan dan tidak memiliki buku manual pemeliharaan, tidak memiliki personel inspektor, personel tidak mendapat pendidikan dan pelatihan, serta pabrik sudah tutup.

Kedua, personel pengambil keputusan kebijakan memiliki keterbatasan pengetahuan, praktik menajemen profesional dan hal bersifat teknis, serta adanya pengaruh intervensi dan bias persepsi dari pemimpin (penguasa) dalam pengambilan keputusan kebijakan.

Seharusnya personel pengambil keputusan kebijakan segera action mengimplementasikan kebijakan yakni: 1) melarang senjata meriam Hanud untuk dioperasikan; dan 2) Mengganti meriam Hanud tersebut dengan pengadaan baru. Namun kenyataannya tidak ada action sama sekali.

Dengan demikian diketahui bahwa pada pembangunan kekuatan senjata meriam Hanud belum ada implementasi kebijakan unggul. Hal ini mencerminkan bahwa personel pengambil keputusan kebijakan memiliki keterbatasan yaitu: pengetahuan, praktik manajemen profesional dan hal bersifat teknis. Hal ini selaras dengan Nugroho (2009: 506-510) menyatakan bahwa setiap kebijakan mempunyai keterbatasan yaitu meliputi keterbatasan waktu, kemampuan SDM, kelembagaan, anggaran, dan hal bersifat teknis.

Tidak adanya implementasi kebijakan yang unggul karena personel pengambil keputusan kebijakan tidak cerdas dan tidak bijaksana. Tidak cerdas, karena memecahkan masalah tidak pada inti permasalahan-nya, dan tidak bijaksana karena justru menghasilkan masalah baru yang lebih besar daripada masalah yang dipecahkan (Nugroho, 2009:706).

Dengan demikian, disimpulkan bahwa "keterbatasan kemampuan SDM berpengaruh terhadap pengambilan keputusan kebijakan".

Akibat dari adanya kebijakan yang tidak unggul, maka pada periode 1962-2002 meriam Hanud tersebut tidak ada proses kebijakan untuk pengadaan senjata baru atau modernisasi.

Dari uraian analisis tentang senjata meriam Hanud disimpulkan bahwa "kebijakan yang tidak unggul berpengaruh terhadap modernisasi persenjataan".

Tahun 2002-2003 terdapat kebijakan pengadaan pengganti meriam Hanud, tetapi oleh pimpinan TNI AU saat itu sasaran diganti menjadi pengadaan Rudal QW-3 yang tidak sesuai dengan usulan institusi pembina yaitu Korpaskhas (yaitu Skyguard buatan Oerlikon, Swiss. Korpaskhas sebagai institusi pembina dan yang mengawaki persenjataan PSU hanya 
menerima hasil kebijakan pengadaan Rudal QW-3. Setelah diuji, ternyata Rudal QW-3 tidak dapat integrasi dengan Radar Hanud dalam Sishanudnas. Padahal kriteria persenjataan PSU yang dibeli mensyaratkan dapat terintegrasi dengan Radar Hanud dalam Sishanudnas. Dengan demikian, pengadaan Rudal QW-3 tersebut tidak sesuai dengan tujuan organisasi atau misi TNI AU yaitu modernisasi PSU menjadi Hanud TNI AU dalam operasi Hanud.

Tidak adanya koordinasi dan tidak adanya informasi dari instansi lain pada implementasi kebijakan pengadaan Rudal QW-3 sehingga akhirnya Rudal QW-3 tidak dapat terintegrasi dengan Radar Hanud dalam Sishanudnas. Hal ini selaras dengan pandangan Subarsono (2010:100) yang menyatakan bahwa implementasi sebuah program perlu dukungan dan koordinasi instansi lain.

Tidak adanya kesepakatan (karena adanya intervensi dari pemimpin atau penguasa) dalam kebijakan pengadaan Rudal QW-3 karena tidak adanya komunikasi dan koordinasi, sehingga Korpaskhas sebagai institusi pembina dan operator hanya menerima hasil kebijakan pengadaan Rudal QW-3 yang tidak sesuai dengan usulan yang diajukan (tidak ada kesepakatan bersama). Hal ini sejalan dengan pendapat Wahab (2010:77) yang menyatakan bahwa setiap kebijakan yang biasanya berupa peraturan yang telah ditetapkan sebagai sumber hukum atau acuan baku yang disepakati secara bersama-sama. Padahal setiap kebijakan harus mendapatkan legitimasi pembenarannya secara hukum atau harus sesuai dengan tata aturan/perundang-undangan yang berlaku.

Dalam kasus pengadaan Rudal QW-3, Nugroho (2009:505) menyatakan bahwa kesalahan mendasar dari pembuat kebijakan adalah hanya mengandalkan semua dalam kondisi ideal. Kebijakan seperti itu sebagai kebijakan yang baik tetapi tidak benar, artinya perumusannya baik, namun implementasinya tidak benar karena ada intervensi. Terkait dengan intervensi, Hill dkk. yang dikutip Nugroho (2009:480) bahwa ada kecenderungan penguasa atau pemimpin mempergunakan government politic model atau leader model, yaitu pengambilan keputusan berdasarkan pada selera penguasa dan kekuasaan.

Berdasarkan data temuan penelitian, sebelumnya telah ada usulan dari Korpaskhas tentang penggantian meriam Hanud dengan meriam Skyguard buatan Oerlikon, Swiss. Tetapi oleh pimpinan TNI AU saat itu sasaran dialihkan pada pengadaan Rudal QW-3, karena adanya vested interest. Selain itu, setiap pengadaan Alutsista dipersyaratkan memenuhi operational requirements dan spesifikasi teknis Alutsista yang akan dibeli. Operational requirements dan spesifikasi teknis mensyaratkan tersedianya teknologi terkini, dan dapat integrasi dengan Radar Hanud dalam Sishanudnas, dalam rangka terwujudnya Hanud TNI AU untuk mendukung operasi Hanud. Namun kenyataannya hasil pengadaan Rudal QW-3 tidak dapat integrasi dengan Radar Hanud dalam Sishanudnas. 
Seharusya hasil pengadaan Rudal QW-3 tersebut sesuai dengan usulan Korpaskhas sebagai institusi pembina sekaligus operator (bottom-up), tetapi senyatanya tidak sesuai dengan usulan tersebut, justru terjadi kebijakan top-down. Seharusnya hasil pengadaan Rudal QW-3 tersebut sesuai dengan operational requirements dan spesifikasi teknis PSU TNI AU (Perkasau/82/VI/2007 tanggal 30 Juni 2007 tentang Operational Requirements Satuan Jajaran TNI AU), namun senyatanya tidak sesuai dengan operational requirements yaitu Rudal QW-3 tidak dapat terintegrasi dengan Radar Hanud dalam Sishanudnas.

Dengan demikian, telah terjadi tidaksinkronnya kebijakan pengadaan Rudal QW-3 dengan pengajuan senjata meriam Hanud oleh satuan operasional dibawahnya (Korpaskhas), dan tidak sinkron dengan kriteria yang dipersyaratkan untuk senjata Hanud TNI AU sebagai salah satu unsur dalam Sishanudnas, karena tidak dapat terintegrasi dengan Radar Hanud.

Sesuai hasil temuan diketahui bahwa pada proses pengadaan Rudal QW-3 tidak ada koordinasi dan informasi dari institusi lain, karena tidak sesuai dengan kebutuhan yang diajukan oleh Korpaskhas sebagai institusi pembina sekaligus operator. Berdasarkan keterangan nara sumber bahwa sasaran pengadaan meriam Hanud telah dialihan menjadi pengadaan Rudal QW-3 oleh pimpinan TNI AU saat itu. Fenomena ini telah dipengaruhi oleh bias persepsi dalam pengambilan keputusan kebijakan oleh penguasa atau pemimpin. Hal ini sejalan dengan pandangan Hill dkk dikutip oleh Nugroho (2009:480) yang menyatakan bahwa "ada kecenderungan penguasa atau pemimpin mempergunakan government leader model atau dominant leader model yaitu pengambilan keputusan berdasarkan pada selera penguasa dan kekuasaan". Selain itu, kebijakan pengalihan sasaran pengadaan meriam Hanud tersebut menjadi pengadaan Rudal QW-3 merupakan indikasi adanya pengaruh bias persepsi dalam pengambilan keputusan kebijakan dan adanya intervensi.

Dari uraian analisis tersebut, disimpulkan sebagai berikut:

Pertama, bahwa terjadi kesenjangan pada personel pengambil kebijakan dalam kebijakan pengadaan Rudal QW-3.

Kedua, personel pengambil kebijakan memiliki keterbatasan aspek pengetahuan, praktik manajemen profesional, dan hal bersifat teknis.

Ketiga, tidak sinkronnya kebijakan pengadaan Rudal QW-3 dengan pengajuan senjata meriam Hanud oleh satuan operasional dibawahnya (Korpaskhas) dan kriteria yang dipersyaratkan untuk senjata Hanud TNI AU sebagai salah satu unsur dalam Sishanudnas. Kondisi demikian belum menggambarkan adanya suatu sistem yang menjamin terdukungnya operasi Sishanudnas dalam pola operasi Hanud (misalnya, terintegrasinya Rudal QW-3 dengan radar Hanud dalam Sishanudnas). 
Dari uraian analisis di atas disimpulkan bahwa 'persepsi dalam pengambilan keputusan berpengaruh terhadap kebijakan'.

Namun, implikasinya bagi pembangunan kekuatan Hanud TNI AU ternyata sangat signifikan. Kenyataannya Rudal QW-3 tidak dapat terintegrasi dengan Radar Hanud dalam Sishanudnas dan tidak memenuhi syarat sebagai senjata Hanud TNI AU, sehingga tidak dapat digunakan dalam operasi Hanud, artinya Rudal QW-3 tersebut tidak dapat mendukung tugas pokok sebagai senjata Hanud TNI AU dalam operasi Hanud.

Operational Requirements dan spesifikasi teknis mempersyaratkan tersedianya teknologi terkini yang menjadi syarat dapat dilakukannya program baru yaitu Alutsista baru yang akan dibeli. Sedangkan sebagai program baru, Alutsista baru yang akan dibeli mempersyaratkan dapat menjamin tercapainya tujuan organisasi yaitu menjadi senjata Hanud TNI AU dalam operasi Hanud yang dilaksanakan oleh Kohanudnas.

Dengan demikian, disimpulkan bahwa 'tersedianya teknologi menjadi syarat dapat dilakukannya suatu program baru dan menjamin pencapaian tujuan organisasi'.

Pada tahun 2005 telah ada kebijakan pengadaan PSU TNI AU dan telah ditetapkan dan disetujui dukungan anggarannya pada TA 2005 dan TA 2006. Proses pengadaan PSU TNI AU pada TA 2005-2006 telah sesuai dengan ketentuan yang berlaku. Hal ini diperkuat dengan adanya dasar yang digunakan dalam pengadaan PSU TNI AU tersebut, yaitu: pertama adalah Peraturan Menteri Pertahanan Nomor: Per/07/VII/2006 tanggal 6 Juli 2006 tentang Tata Cara Pengadaan Barang/Jasa Militer dengan menggunakan Fasilitas Kredit Ekspor di lingkungan Departemen Pertahanan dan Tentara Nasional indonesia; kedua adalah Surat Menko Perekonomian Nomor: SR206/M.EKON/09/2005 tanggal 12 September 2005 hal alokasi Kredit Ekspor TA. 2005 Departemen Pertahanan/TNI; ketiga adalah Surat Menteri Negara PPN/Ka Bappenas Nomor: 7610/M.PPN/12/2006 tanggal 26 Desember 2006 perihal Alokasi Pinjaman Hibah Luar Negeri (PHLN) atau Kredit Ekspor (KE) TA. 2006 untuk Departemen Pertahanan. Namun, pada awal tahun 2007 ternyata tidak ada dukungan anggaran untuk pengadaan PSU TNI AU.

Sejak awal proses pengadaan PSU TNI AU terjadi perbedaan penggunaan operational requirements dan spesifikasi teknis yang digunakan sebagai kriteria dasar pengukuran kualitas PSU TNI AU yang akan dibeli, terutama tersedianya teknologi. Pada konteks ini terjadi perbedaan pandangan dan pertimbangan antara Mabes TNI dan Mabesau. Mabes TNI menggunakan operational requirements dan spesifikasi teknis tahun 2004 yaitu Surat Keputusan Kasau Nomor: 84/VI/2004 tanggal 16 Juni 2004 tentang Buku Petunjuk Operasi Pertahanan Pangkalan. Sedangkan Mabesau menggunakan Peraturan Kasau Nomor: Perkasau/82/VI/2007 tangal 30 Juni 2007 tentang Operational Requirements Satuan Jajaran TNI AU. Inti dari perbedaan 
kedua peraturan ini adalah penggelaran persenjataan PSU dalam satu Satuan Tembak (Satbak). Mabes TNI menyatakan dalam satu Satbak adalah 3 pucuk (Skep Kasau No.84/VI/2004 tentang Bujuknis TNI AU tentang Operasi Pertahanan Pangkalan) dan Mabesau menyatakan dalam satu Satbak adalah 2 pucuk (Perkasau/82/VI/2007 tentang operational requirements dan Spesifikasi Teknis Satuan Jajaran TNI AU). Jika ditinjau sekilas memang sederhana, tetapi karena data persenjataan dalam satu Satbak itu nantinya akan digunakan dalam dasar perhitungan jumlah persenjataan yang akan dibeli dalam jumlah besar, sehingga perbedaannya akan sangat signifikan. Selain itu dalam penentuan gelar persenjataan meriam Hanud tersebut di lapangan akan berbeda, terutama untuk strategi penangkalan dalam menghadapi ancaman. Jadi, perbedaan masalah teknis ini menjadi sangat penting dalam menentukan jumlah senjata meriam dan Rudal dalam satu Satbak.

Selanjutnya, dalam penentuan operational requirements dan spesifikasi teknis PSU TNI $\mathrm{AU}$ terkait erat dengan tersedianya teknologi persenjataan. Mengingat dinamika perkembangan dan kemajuan teknologi persenjataan sangat cepat, maka PSU TNI AU senantiasa mengadopsi teknologi terkini. Jika tidak, maka teknologinya akan cepat ketinggalan (obsolete). Kecepatan dan dinamika perkembangan teknologi berpengaruh besar terhadap persenjataan. Sedangkan muatan teknologi persenjataan mempengaruhi kualitas SDM yang mengawakinya serta organisasi yang berbobot teknologi. Fenomena teknologi PSU yang obsolete menjadi bukti terjadinya perdebatan mengenai tersedianya teknologi pada PSU pengganti.

Dengan demikian, disimpulkan bahwa tersedianya teknologi menjadi syarat dapat dilaksanakannya suatu program baru untuk pencapaian tujuan organisasi.

Terjadinya bias persepsi (perbedaan pandangan dan pertimbangan) antara Mabes TNI dan Mabesau tentang operational requirements dan spesifikasi teknis PSU TNI AU dianalisis dengan menggunakan analysis of policy (analisis tentang kebijakan) yaitu menganalisis seluruh proses kebijakan dan metode deskriptif (mendeskripsikan kebijakan masa lalu dan saat ini). Dari kedua metode analisis tersebut ditemukan implementasi kebijakan sebagai berikut:

Pertama, terdapat ketidaksesuaian implementasi atas tindakan yang dilakukan oleh Mabes TNI melalui koordinasi dengan Mabesau tentang Perkasau/82/VI/ 2007 tanggal 30 Juni 2007 tentang Operational Requirements Satuan Jajaran TNI AU.

Kedua, pada implementasi kebijakan Mabes TNI masih menggunakan Skep Kasau Nomor 84/VI/2004 tanggal 16 Juni 2004 tentang Operasi Pertahanan Pangkalan.

Penelitian ini mengkombinasikan metode deskriptif dan penelitian tindakan. Metode deskriptif digunakan untuk mendeskripsikan kebijakan masa lalu dan saat ini, seperti perbedaan pandangan dan pertimbangan tentang operational requirements dan spesifikasi teknis 
PSU TNI AU antara Mabes TNI dan Mabesau, sedangkan penelitian tindakan adalah tindakan personel pengambil keputusan kebijakan. Perbedaan penggunaan operational requirements dan spesifikasi teknis PSU TNI AU dinilai berdasarkan kesesuaian antara implementasi kebijakan yang seharusnya dibandingkan dengan implementasi kebijakan yang senyatanya.

Kenyataannya Perkasau/82/ VI/2007 tanggal 30 Juni 2007 tentang Operational Requirements Satuan Jajaran TNI AU adalah lebih update dibandingkan Skep Kasau Nomor:84/VI/2004 taggal 16 Juni 2004 tentang Buku Petunjuk Teknis Operasi Partahanan Pangkalan. Seharusnya Mabes TNI menggunakan operational requirements dan spesifikasi teknis tahun 2007, tetapi senyatanya tidak demikian, sehingga disimpulkan bahwa telah terjadi kesenjangan pada personel pengambil keputusan kebijakan pada tataran strategis dan operasional.

Berdasarkan data temuan penelitian diketahui bahwa dari ketiga calon pemenang penyedia barang/jasa telah dilaksanakan peninjauan ke pabrik/ fasilitas barang/jasa dan demo produk sesuai dengan ketentuan pengadaan barang/jasa di ke tiga fasilitas barang/jasa. Peninjauan ini berdasarkan operational requirements dan spesifikasi teknis yang telah dipersyaratkan. Dari hasil peninjauan diketahui bahwa "Oerlikon Contraves-AG", Swiss memenuhi persya-ratan, sedangkan "Defex”, Spanyol dan “Thales", Belanda tidak memenuhi beberapa persyaratan.
Berdasarkan ketentuan, semestinya "Oerlikon Contraves-AG", Swiss sebagai pemenang dan dilanjutkan dengan proses pengadaan berikutnya. Dalam konteks ini pelaksanaan peninjauan dan hasilnya semestinya telah memenuhi ketentuan yang dipersyaratkan, sehingga hasilnya adalah tidak ada intervensi dari pihak manapun apalagi personel tersebut berada dalam Tim atau kelompok yang independen. Hal ini didasarkan pada ketentuan, yaitu bahwa personel dalam Tim yang dikirim ke seluruh fasilitas penyedia barang/jasa merupakan personel yang memiliki kompetensi dan profesi di bidangnya masingmasing. Artinya, para personel dalam Tim itu telah memenuhi kriteria knowledge dan skill serta kualitas individu sesuai kecabangan/korps.

Keberadaan personel dalam Tim didukung dengan Surat Perintah resmi di jajaran Kemhan/TNI sesuai dengan prosedur pengadaan barang/jasa militer (Peraturan Menteri Nomor: PER/07/M/VII/2006 tanggal 16 Juli tahun 2006). Tetapi kenyataannya hasil yang dilaporkan oleh personel dalam Tim peninjauan ke fasiitas penyedia barang/jasa tidak mendapat respon positif. Buktinya masih dilaksanakan peninjauan dan demo ulang ke fasilitas barang/jasa oleh dua pejabat Kemhan dalam rangka klarifikasi terhadap hasil peninjauan ke fasilitas barang/jasa yang telah dilaksanakan sebelumnya. Hal ini menunjukkan bahwa penerapan implementasi kebijakan memiliki keterbatasan pada aspek pengetahuan, praktik manajemen profesional, dan keterbatasan hal teknis serta adanya persepsi dan 
intervensi. Dengan demikian, penerapan implementasi kebijakan tersebut tidak unggul. Implementasi kebijakan yang tidak unggul, karena beberapa alasan, yaitu:

Pertama, proses pengadaan PSU dengan menggunakan anggaran PHLN/KE telah sesuai ketentuan atau prosedur dan melalui tahapan yang dilaksanakan oleh beberapa instansi terkait, artinya, dilaksanakan secara terbuka. Selain itu, dasar yang digunakan telah sesuai dengan ketentuan hukum dan prosedur yang berlaku. Namun kenyataannya terjadi kesenjangan pada proses pengadaan PSU.

Kedua, semestinya tidak perlu dilaksanakan peninjauan ulang ke fasilitas barang/jasa oleh dua pejabat Kemhan, karena sebelumnya telah dilaksanakan peninjuan ke fasilitas barang/jasa oleh Tim expert. Personel dalam Tim tersebut telah memiliki kriteria yang dipersyaratkan terkait pada hal teknis. Jika peninjauan ulang dilaksanakan oleh pejabat yang tidak proporsinya justru tidak tepat, karena tujuan peninjauan mempersyaratkan dimilikinya kriteria knowledge dan skill pada aspek teknis.

Ketiga, setelah keputusan pemenang oleh instansi yang berwenang, tetapi tidak didukung oleh institusi dibawahnya, justru permintaan paraf persetujuan sebagai syarat penentuan pemenang bagi penyedia barang/jasa tidak dilaksanakan. Hal ini diperkuat dengan pernyataan bahwa rapat koordinasi yang telah dilaksanakan dan dihadiri oleh seluruh instansi terkait dianggap tidak pernah ada. Hal ini kurang tepat karena dalam forum rapat koordinasi telah dihadiri oleh personel dari seluruh instansi terkait. Ditinjau dari aspek perilaku individu personel pengambil kebijakan dipengaruhi oleh persepsi yang bias.

Hasil peninjauan sebelumnya oleh Tim telah memenuhi syarat dan sah menurut hukum. Seharusnya tidak perlu dilaksanakan peninjauan ulang ke fasilitas penyedia barang/jasa, tetapi senyatanya peninjauan ulang ke fasilitas penyedia barang/jasa tetap dilaksanakan, sehingga disimpulkan bahwa telah terjadi kesenjangan pada implementasi kebijakan pengadaan PSU TNI AU khususnya pada personel pengambil kebijakan pada tataran strategis.

Selanjutnya masih dilaksanakan rapat sinkronisasi operational requirements dan spesifikasi teknis PSU. Hal ini merupakan bukti bahwa pelaksanaan proses pengadaan PSU tidak konsisten dengan ketentuan pengadaan barang/jasa militer yang berlaku.

Penelitian ini mengkombinasikan metode deskriptif dan penelitian tindakan. Metode deskriptif digunakan untuk mendeskripsikan kebijakan masa lalu dan saat ini, seperti kasus rapat sinkronisasi operational requirements dan spesifikasi teknis PSU, sedangkan penelitian tindakan adalah tindakan personel pengambil kebijakan. Jadi, pelaksanaan rapat sinkronisasi operational requirements dan spesifikasi teknis PSU setelah dilaksanakan peninjauan ke fasilitas pabrik penyedia barang/jasa akan dinilai kesesuaian antara implementasi kebijakan yang seharusnya dibandingkan dengan implementasi kebijakan yang senyatanya. 
Operational requirements dan spesifikasi teknis yang dikeluarkan oleh Mabesau digunakan sebagai indikator keberhasilan pengadaan PSU TNI AU. Seharusnya tidak perlu dilaksanakan rapat sinkronisasi operational requirements dan spesifikasi teknis setelah dilaksanakan peninjauan ke pabrik penyedia barang/jasa. Semestinya rapat sinkronisasi operational requirements dan spesifikasi teknis itu dilaksanakan jauh sebelum dilaksanakan peninjauan ke fasilitas barang/jasa, karena operational requirements dan spesifikasi teknis PSU tersebut dijadikan indikator keberhasilan pengadaan PSU. Tetapi senyatanya pelaksanaan rapat sinkronisasi operational requirements dan spesifikasi teknis tersebut tidak sesuai dengan ketentuan yang berlaku.

Terjadinya peninjauan ulang ke fasilitas barang/jasa karena personel pengambil keputusan kebijakan pada tataran strategis tidak memiliki informasi dari luar yang akurat tentang hasil peninjauan, sehingga terjadi bias antara fakta situasi obyektif dengan realitas individual yang bersifat subyektif. Hal ini sejalan dengan pandangan Rowe dan Boulgarides (1992, dalam Sarwono dan Meinarno, 2009:208) yang menyatakan:

"Pada kenyataannya, informasi yang diperoleh melalui persepsi tentang suatu situasi atau masalah melibatkan bias antara fakta situasi obyektif dengan realitas individual yang bersifat subyektif. Adanya bias persepsi ini akan mempengaruhi interpretasi dan reaksi individu terhadap situasi yang pada akhirnya akan membedakan antara gaya individu yang satu dengan lainnya dalam mengambil keputusan".

Dari uraian analisis di atas, diketahui bahwa telah terjadi ketidaksesuaian implementasi atas tindakan oleh personel pengambil keputusan kebijakan pada tataran strategis dan operasional, khususnya dalam implementasi peninjauan ulang dan dilaksanakannya rapat sinkronisasi operational requirements dan spesifikasi teknis setelah dilaksanakan peninjauan ke fasilitas penyedia barang/jasa.

Personel pengambil keputusan kebijakan pada tataran strategis dan operasional memiliki keterbatasan SDM (pengetahuan), keterbatasan kelembagaan (praktik manajemen profesional) dan hal bersifat teknis. Selain itu, penerapan implementasi kebijakan tersebut telah dipengaruhi oleh persepsi dalam pengambilan keputusan.

Dengan demikian, disimpulkan bahwa 'persepsi dalam pengambilan keputusan berpengaruh terhadap kebijakan'

Setelah kebijakan pengadaan Rudal QW-3 belum berhasil integrasi dengan Radar Hanud, kemudian ada kebijakan pengadaan Radar Smart Hunter yang diharapkan dapat menjembatani Rudal QW-3 agar dapat integrasi dengan Radar Hanud dalam Sishanudnas. Namun, kenyataannya Radar Smart Hunter hanya mampu mengarahkan Rudal QW-3 ke sasaran saja, tetapi Rudal QW-3 tidak dapat terintegrasi dengan Radar Hanud dalam Sishanudnas.

Dari uraian pembahasan tentang kebijakan pengadaan PSU TNI AU sejak dioperasikan 
pada tahun 1962 hingga akhir tahun 2013, disimpulkan sebagai berikut:

Pertama, implementasi kebijakan pengadaan PSU TNI AU ada vested interest, sehingga tidak ditujukan untuk kepentingan organisasi TNI, yaitu misi operasi Hanud dalam rangka mendukung operasional Kohanudnas.

Kedua, selama 40 tahun (1962-2002) tidak ada implementasi kebijakan modernisasi PSU, padahal telah ada indikasi terhadap semakin menurunnya kuantitas maupun kualitas persenjataan meriam Hanud. Selain itu, kejadian kecelakaan meriam Hanud merupakan akibat dari implementasi kebijakan yang tidak unggul.

Ketiga, adanya kebijakan pengadaan Rudal QW-3 yang tanpa koordinasi yang solid dengan instansi terkait merupakan implementasi kebijakan yang dipengaruhi oleh persepsi dan intervensi.

Keempat, kebijakan pengadaan PSU sejak tahun 2005 dan tertunda sampai dengan tahun 2013 dan terjadi perbedaan pandangan dan pertimbangan antara kedua institusi TNI. Hal ini merupakan indikasi tidak adanya sinkronisasi kebijakan.

Dengan demikian disimpulkan bahwa 'modernisasi peralatan (PSU) mempersyaratkan adanya sinkronisasi kebijakan pada tataran strategis dan operasional untuk mendukung tujuan organisasi'.

Personel pengambil keputusan kebijakan belum memiliki kompetensi sesuai profesinya serta tidak adanya koordinasi dan informasi yang baik. Hal ini ditunjukkan dengan adanya perbedaan

penggunaan

operational requirements dan spesifikasi teknis dalam pengadaan PSU.

Dari keseluruhan permasalahan kebijakan di atas, individu personel pengambil keputusan kebijakan dipengaruhi oleh beberapa faktor, utamanya persepsi dalam pengambilan keputusan.

Tertundanya modernisasi PSU karena adanya kebijakan yang tidak unggul, yaitu: pertama adalah memecahkan masalah tidak pada inti permasalahannya; kedua adalah menghasilkan masalah baru yang lebih besar daripada masalah yang dipecahkan, seperti kebijakan pengadaan Rudal QW-3 dan Radar Smart Hunter yang tidak bisa terintegrasi dengan Radar Hanud dalam Sishanudnas, sehingga tidak bisa mendukung tugas pokok operasi Hanud. Selain itu, kebijakan pengadaan PSU sejak TA. 2005 hingga TA. 2013 belum terealisasi, bahkan sampai dengan bulan Agustus 2013 masih bersifat 'status quo' karena belum ada keputusan yang pasti.

Sesuai data temuan penelitian bahwa pada TA. 2005-2009 telah diprogramkan pengadaan PSU dan telah ditindak lanjuti dengan penetapan anggaran. Setelah proses pengadaan berjalan selama 2 tahun (2005-2006), ternyata anggaran tersebut tidak ada realisasinya, sehingga pengadaan PSU dilaksanakan proses ulang.

Setelah proses pengadaan berjalan selama 8 tahun dan sampai dengan tahun 2013 belum ada realisasinya. Bahkan untuk menentukan pemenang Penyedia Barang/Jasa terjadi perbedaan pandangan dan pertimbangan (bias 
persepsi) antara Mabes TNI dan Mabesau tentang operational requirements dan spesifikasi teknis PSU yang akan dibeli.

Pejabat Kemhan melaksanakan peninjauan ulang ke fasilitas/pabrik penyedia barang/jasa untuk konfirmasi secara fisik. Setelah disimpulkan dan ditentukan pemenangnya oleh Kemhan, ternyata Mabes TNI memberikan pendapat yang berbeda. Sebelumnya telah ditunjuk Tim independen sesuai bidang keahliannya untuk melaksanakan peninjauan ke pabrik/penyedia barang/jasa. Setelah hasil peninjauan dilaporkan, ternyata masih dilaksanakan peninjauan ulang oleh pejabat Kemhan.

Terjadinya permasalahan pada pengadaan PSU sehingga tertunda lebih dari 8 tahun karena SDM keterbatasan kemampuan yaitu kurangnya kompetensi dalam penerapan implementasi kebijakan. Kasus pengadaan PSU selaras dengan pandangan Hill dkk seperti dikutip oleh Nugroho (2009:480) bahwa ada kecenderungan penguasa atau pemimpin yang mempergunakan Government Politics Model atau Dominant Leader Model yaitu pengambilan keputusan berdasarkan pada selera penguasa dan kekuasaan. Kondisi ini menurut Nugroho (2009: 480) bahwa personel staf hanya bertindak "polishing the boss" atau menjustifikasi keinginan pemimpinnya.

Dari keseluruhan analisis kebijakan pembangunan kekuatan Hanud periode 19902013 diketahui bahwa personel pengambil keputusan kebijakan memiliki keterbatasan pengetahuan, praktik manajemen profesional, dan hal bersifat teknis. Implementasi kebijakan dipengaruhi oleh bias persepsi dan intervensi, sehingga implementasi kebijakan tersebut tidak unggul. Alasannya yaitu: pertama, personel pengambil keputusan kebijakan tidak cerdas dan tidak tidak bijaksana. Tidak cerdas, karena memecahkan masalah tidak pada inti permasalahannya. Tidak bijaksana, karena implementasi kebijakan yang diterapkan justru menghasilkan masalah baru yang lebih besar daripada masalah yang dipecahkan.

Dengan demikian diketahui bahwa telah terjadi gap pada proses pengadaan PSU TNI AU, dalam menentukan operational requirements dan spesifikasi teknis. Secara keseluruhan diketahui bahwa dalam proses pengadaan PSU TNI AU telah terjadi kesenjangan implementasi kebijakan yang diterapkan oleh SDM pengambil keputusan kebijakan.

Dengan adanya gap tersebut, maka proses pengadaan PSU TNI AU menjadi lebih panjang (tidak ideal) karena tidak sesuai dengan ketentuan yang ada dan sampai dengan bulan Agustus 2013 terjadi "status quo". Untuk lebih jelasnya digambarkan dengan membandingkan alur proses pengadaan PSU TNI AU pada 'kondisi ideal' dengan alur proses pengadaan PSU TNI AU pada 'kondisi terjadi kesenjangan' seperti gambar dibawah ini: 


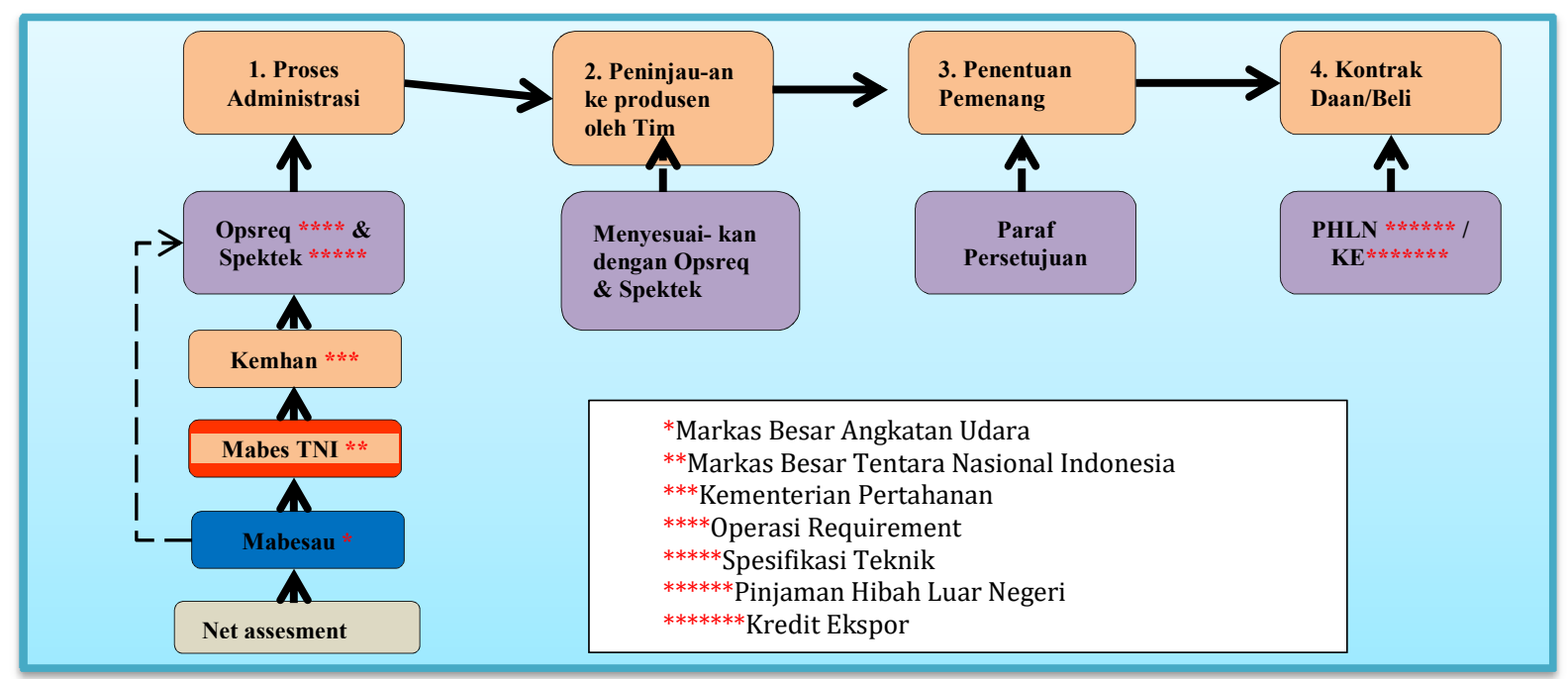

Gambar : Alur Proses Pengadaan PSU TNI AU (Kondisi Ideal)

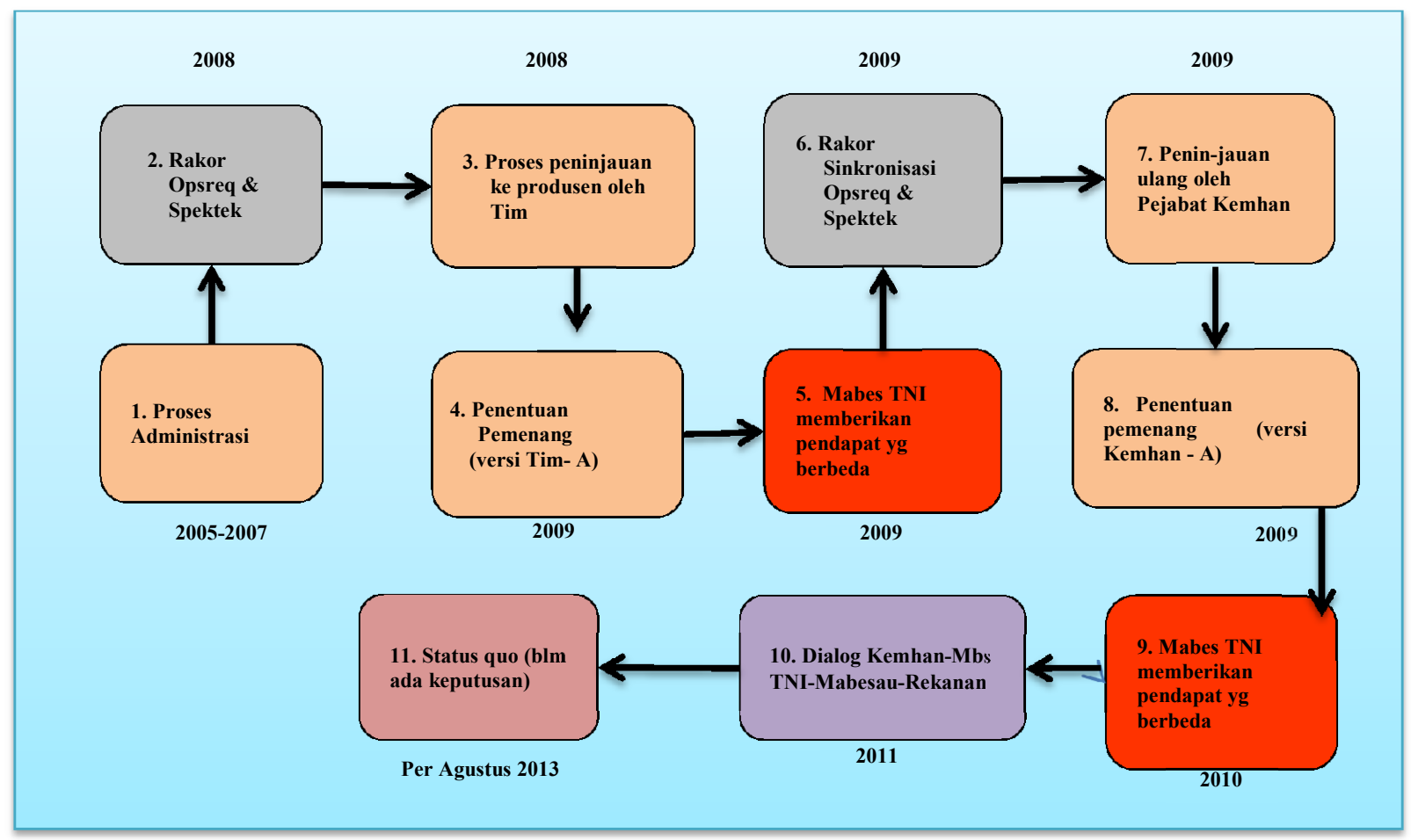

Gambar : Alur Proses Pengadaan PSU TNI AU (Kondisi terjadi Kesenjangan)

Dari pembahasan data temuan penelitian tentang implementasi kebijakan pembangunan kekuatan Hanud, didapatkan 4 proposisi, yakni: Proposisi 1: "Persepsi dalam pengambilan keputusan berpengaruh terhadap kebijakan".
Proposisi 2: "Keterbatasan

kemampuan sumber daya manusia berpengaruh terhadap pengam-bilan kebijakan".

Proposisi 3: "Modernisasi

peralatan mempersyaratkan adanya 
sinkronisasi kebijakan pada tataran strategis dan operasional untuk mendukung tujuan organisasi”.

Proposisi 4: "Tersedianya teknologi menjadi syarat dapat dilaksanakannya suatu program baru untuk pencapaian tujuan organisasi”.

\section{KESIMPULAN}

1. Terjadi gap pada personel pengambil keputusan kebijakan pembangunan kekuatan Hanud TNI AU pada periode 1990-2013. Kesenjangan terjadi karena inkonsistensi antara rumusan kebijakan dan implementasi kebijakan sehingga tidak unggul. Implementasi kebijakan tidak unggul karena personel pengambil keputusan kebijakan tidak cerdas dan tidak bijaksana.

Tidak cerdas, karena memecahkan masalah tidak pada inti permasalahannya, dan tidak bijaksana karena justru menghasilkan masalah baru yang lebih besar daripada masalah yang dipecahkan. Hal ini terjadi karena ada kecenderungan penguasa atau pemimpin mempergunakan Government Politics Model atau Dominant Leader Model yaitu pengambilan keputusan berdasarkan pada selera penguasa dan kekuasaan. Implikasinya, proses pengadaan PSU TNI AU sejak tahun 2005 hingga Agustus 2013 bersifat "status quo" (belum ada realisasinya).

2. Tidak sinkronnya kebijakan pengadaan PSU dengan kebutuhan operasi. Hal ini ditunjukkan dengan beberapa fenomena sebagai berikut: a. Tidak ada penerapan implementasi kebijakan oleh personel pengambil keputusan kebijakan tentang modernisasi meriam Hanud, sehingga setelah dioperasikan lebih dari 40 tahun teknologinya obsolete, tidak dapat memenuhi kriteria yang dipersyaratkan dalam operational requirements dan spesifikasi teknis sebagai senjata Hanud TNI AU.

b. Tidak sinkronnya kebijakan pengadaan Rudal QW-3 dengan pengajuan senjata meriam Hanud oleh Satuan operasional (Korpaskhas) serta kriteria yang dipersyaratkan untuk senjata Hanud TNI AU sebagai salah satu unsur dalam Sishanudnas, sehingga tidak terintegrasinya Rudal QW-3 dengan Radar Hanud dalam Sishanudnas.

c. Tidak sinkronnya kebijakan pengadaan PSU TNI AU karena ada bias persepsi antara Mabes TNI dengan Mabesau dalam penentuan operational requirements dan spesifikasi teknis yang digunakan sebagai dasar acuan.

d. Tidak sinkronnya kebijakan pengadaan Radar Smart Hunter dengan tujuan terintegrasinya senjata Hanud TNI AU dengan Radar Hanud dalam Sishanudnas. Realisasinya Radar Smart Hunter tidak dapat menjembatani Rudal QW-3 untuk dapat terintegrasi dengan Radar Hanud dalam Sishanudnas.

e. Tidak konsisten dalam menerapkan kebijakan yang sudah dibuat tentang 
pengoperasian Alutsista akibat pengaruh faktor internal, yaitu pengetahuan, praktik manajemen profesional, dan faktor teknis.

3. Tidak sinkronnya kekuatan senjata dengan kekuatan personel dan organisasi, sehingga terjadi kesenjangan antara kuantitas dan kualitas organisasi, senjata serta kuantitas dan kualitas SDM.

Hal ini disebabkan oleh adanya kecenderungan penguasa/pemimpin mempergunakan Governant Politics Model atau Dominant Leader Model yaitu pengambilan keputusan berdasarkan pada selera penguasa dan kekuasaan.

\section{SARAN}

Saran praktis kepada institusi Kemhan dan Mabes TNI/TNI AU adalah:

1. Perlu penentuan batas waktu pengoperasian PSU TNI AU sesuai kebutuhan operasi; kebijakan pengadaan PSU TNI AU agar menganut sistem "bottom-up" sesuai kebutuhan operasi dan teknologi, serta sinkronisasi antara kuantitas dan kualitas senjata dengan kuantitas dan kualitas personel dan organisasi.

2. Perlu penataan ulang persenjataan PSU TNI AU yang akan digelar di tiap Batalyon Korpaskhas untuk melindungi Lanud Induk TNI $\mathrm{AU}$.

3. Perlu penataan ulang personel pengawak PSU TNI AU, terdiri dari berbagai disiplin ilmu dan kecabangan/ korps. Dalam hal ini perlu sinkronisasi antara kuantitas dan kualitas senjata dengan kuantitas dan kualitas SDM yang akan mengawakinya.

4. Perlu restrukturisasi organisasi PSU TNI AU berikut pengisian postur organisasi melalui TOA/TOD dari komoditi korps masing-masing. Pada konteks ini diharapkan ada masukan tentang sinkronisasi antara kuantitas dan kualitas senjata dengan kuantitas dan kualitas organisasi.

\section{DAFTAR PUSTAKA}

Chatab, Nevizond. (2009). Mengawal Pilihan Rancangan Organisasi. Bandung: Alfabeta.

Dephan RI. (2007) Doktrin Pertahanan Negara. Jakarta: Dephan RI.

http://kopiitudashat.wordpress.com/2009/07/14 /deterrence-dan compellence-sebagaistrategic-of-military-defence. diakses tanggal 16 Juni 2011.

http://theamazing-grace.blogspot.com/2010/03/ pengaruh-deterrences dan-compliance. html. diakses tanggal 16 Juni 2011.

http://himashiunand.blogspot.com/2011/05/joh nfrietzgerald-kenedy-dalam-krisis.html. Diakses tanggal 16 Juni 2011

http://buletinlitbang.dephan.go.id/index. asp? vnomor $=21 \&$ mnorutisi $=3 \quad$ diakses tanggal 2 Januari 2011.

Kohanudnas. (2009). Rencana Strategis Penataan Kohanudnas Ke Depan.

Kopiitudashat. Juli 14, 2009

Mabesau. (2010). Pembangunan Kekuatan Pokok Minimum (Minimum Essential Force) TNI AU Tahun 2010-2024. Jakarta: Dispenau.

Phoenix. (2009). Kamus Besar Bahasa Indonesia Edisi Baru. Jakarta: PT. Media Pustaka Phoenix. 
Peraturan Presiden RI Nomor 54 Tahun 2010 tentang Pengadaan Barang/Jasa Pemerintah.

Peraturan Menteri Pertahanan RI Nomor: PER/07/M/VII/2006 tanggal 6 Juli 2006 tentang Tata Cara Pengadaan Barang/Jasa Militer Dengan Menggunakan Fasilitas Kredit Ekspor di Lingkungan Departemen Pertahanan dan Tentara Nasional Indonesia.

Peraturan Panglima TNI Nomor Perpang/04/IX/2010 tanggal 29 September 2010 tentang POP Kohanudnas. Jakarta.

Peraturan Kepala Staf TNI Angkatan Udara Nomor Perkasau/82/VI/2007 tanggal 30 Juni 2007 tentang Buku Petunjuk Pelaksanaan TNI AU tentang Operational Requirements Satuan Jajaran TNI Angkatan Udara, Jakarta: Mabesau .

Peraturan Kepala Staf Angkatan Udara Nomor Perkasau/79/XII/2007 tanggal 13 Desember 2007 tentang Buku Petunjuk Pelaksanaan TNI AU tentang Operasi Pertahanan Udara.

Peraturan Kepala Staf Angkatan Udara Nomor Perkasau/71/IX/2010 tanggal 17 September 2010 tentang Rencana Strategis Pembangunan TNI Angkatan Udara Tahun 2010-2014.

Peraturan Panglima Kohanudnas Nomor Perpang/04/ IX/2010 tanggal 29 September 2010 tentang Prosedur Tetap Operasi Pertahanan Udara Nasional.

Paramita, Gracia. Jurnal THI V, April 15, 2009

Perkasa, Surya. Mei 5, 2011

Priyono, Eddy. Balitbang, Kemhan, Desember 21, 2010.

RI, D. P. (2008). Buku Putih Pertahanan Indonesia. Jakarta: Departemen Pertahanan Republik Indonesia.

Setyosari, H.P. (2010). Metode Penelitian Pendidikan dan Pengembangan. Jakarta: Kencana.
Sugiyono. (2013). Metode Penelitian Kuantitatif, Kualitatif dan $R \& D$. Bandung: Alfabeta.

Wee, CH. (2009). Art Of War. Jakarta: PT. Bhuana Ilmu Populer Kelompok Gramedia. 